TI 2011-136/3

Tinbergen Institute Discussion Paper

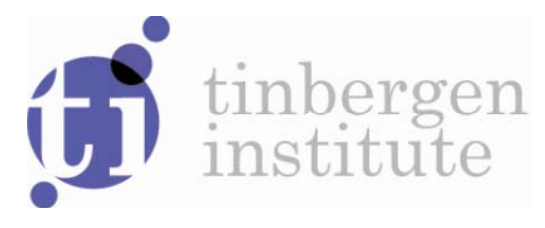

Migration and Foreign Direct Investment: Education Matters

Masood Gheasi

Peter Nijkamp*

Piet Rietveld*

Faculty of Economics and Business Administration, VU University Amsterdam.

* Tinbergen Institute 
Tinbergen Institute is the graduate school and research institute in economics of Erasmus University Rotterdam, the University of Amsterdam and VU University Amsterdam.

More TI discussion papers can be downloaded at http://www.tinbergen.nl

Tinbergen Institute has two locations:

Tinbergen Institute Amsterdam

Gustav Mahlerplein 117

1082 MS Amsterdam

The Netherlands

Tel.: +31(0)205251600

Tinbergen Institute Rotterdam

Burg. Oudlaan 50

3062 PA Rotterdam

The Netherlands

Tel.: +31(0)10 4088900

Fax: $+31(0) 104089031$

Duisenberg school of finance is a collaboration of the Dutch financial sector and universities, with the ambition to support innovative research and offer top quality academic education in core areas of finance.

DSF research papers can be downloaded at: http://www.dsf.nl/

Duisenberg school of finance

Gustav Mahlerplein 117

1082 MS Amsterdam

The Netherlands

Tel.: +31(0)20 5258579 


\title{
Migration and Foreign Direct Investment: Education Matters
}

\author{
Masood Gheasi, Peter Nijkamp and Piet Rietveld \\ Dept. of Spatial Economics \\ VU University \\ Amsterdam, The Netherlands \\ m.a.g.gheasi@vu.nl
}

\begin{abstract}
The rapid growth in the foreign-born population in many high and middle-income countries in recent decades has prompted much research on the socio-economic determinants and impacts of immigration. This paper investigates the relationship between the stock of foreign population by nationality living in the UK and the bilateral volume of foreign direct investment (FDI), both inward FDI into the UK and outward FDI from the UK. This study contributes to the literature on the abovementioned association between migration and FDI, by using the UK annual data from 2001 to 2007 for 22 countries on the inward volume of FDI and for 27 countries on the outward volume of FDI. Our study finds a significant and positive relationship between migration and outward FDI. This result also holds, if we correct for endogeneity by using an instrumental variable approach. If we then include the education level of migrants living in the UK, our results indicate that the more educated migrants from a certain country are, the stronger positive effect they have on FDI in both directions (inward and outward).
\end{abstract}

Keywords: foreign direct investment, immigration, gravity model, instrumental variable 


\section{Introduction}

The globalization process in the past decades has exerted a great impact on economic activities (including export and imports) in many nations. The decline in transportation and communication costs made also the people's movement easier and cheaper. The softening of policy barriers has further facilitated cross-border investments and has increased the flow of goods, capital, people and knowledge across international borders. As a result, open economies are nowadays quickly integrating and becoming more closely dependent on each other.

Migration as a structural cross-border flow of humans has increased significantly in the past decades. The United Nations has indicated that the stock, of international migrants has increased from 75 to about 200 million between 1960 and 2005. The inflow of foreign direct investment (FDI) has also shown an upward trend and increased from 225 \$ billion in 1990 to 1,979 \$ billion in 2007 (UNCTAD, reports 1992 and 2009). Migration is not a stand-alone activity; immigrants may stimulate international trade and remove bilateral investment barriers, because immigrants bring with them their own national culture, traditions and language. They also have often deep market information, which is crucial for international investors. These factors reduce the transaction costs and may enhance and facilitate FDI and trade flows between the host country and the country of origin. Thus, it seems plausible that an increase in the stock of immigrants from a particular country may be accompanied by an increase in FDI.

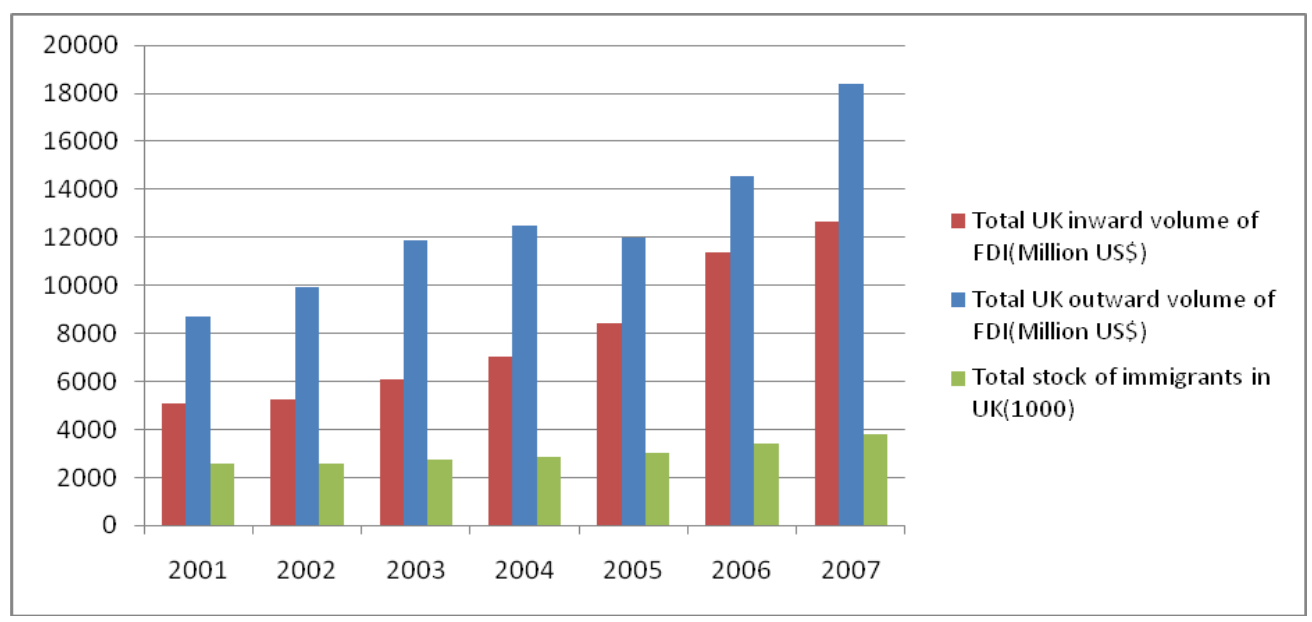

Figure 1: Worldwide stock of immigrants, inward FDI and outward FDI in the UK Source: Authors' calculation based on OECD database

Empirical data show that the majority of the OECD countries are the final destination for the largest part of international migration movements. Immigration movement not only happens from outside OECD countries, but there is also a major migration movement between OECD countries. The foreign-born population in 2006 accounted for 11.7 percent of the total population in OECD countries, which shows an increase of 18 percent compared to the year 2000 (International Migration Outlook: SOPEMI, 2008). The UK, as one of the bigger OECD countries, has always been one of the most important destinations for migrants (from outside OECD countries as well as from inside). This country has received a significant number of immigrants over the period of 2000 to 
2007. The stock of foreign-born population in the UK (in percentage of total population) increased from 4.0 percent in 2000 to 10.1 percent in 2006, giving the UK a net rise of 6.1 percent in 6 years. There is also an upward trend in the stock of FDI both inward into and outward from the UK during the above mentioned period. Figure 1 offers information on inward FDI, outward FDI and the stock of immigrants from 2001 to 2007 in the UK.

Our study seeks to explore the applicability of international trade theory, by using in particular the so-called gravity model or spatial interaction model, to modeling FDI flows. In our applied work, we will use a panel data approach to analyze cross-sectional and time-series data the same time. In this study, we look at the relationship between the stock of immigrants and the bilateral volume of FDI (inward and outward), with $22^{1}$ countries for inward FDI and $27^{2}$ countries for outward FDI, for the years 2001 to 2007 for the UK. As there is a potential endogeneity of migration with respect to $\mathrm{FDI}$, we also use an instrumental variable approach to further investigate this causality relationship. The remaining part of the paper is organized as follows: the next section presents a concise literature review, while Section 3 offers a statistical estimation approach for our study. Then, Section 4 shows the data sources and some data explorations, while Section 5 presents the empirical model results obtained from the data. Finally, Section 6 provides some concluding remarks.

\section{Literature Review}

The rapid growth in the foreign-born population in many high and middle-income countries in recent decades has prompted much research on the socio-economic dimensions of immigration. This is particularly due to the fact that immigration is not a stand-alone activity; for instance, flows of immigrants may influence international trade and investment barriers, since immigrants bring with them their specific indigenous culture, tradition, language, and market information. Various econometric studies conducted since the early 1990s show that immigration has a statistically significant impact on merchandise trade and FDI.

A number of studies have shown indeed that migrant networks contribute to reduce transaction costs between the host country and country of origin. The role migrants can play in promoting bilateral trade and investment is nowadays well recognized, thanks to the seminal work of Gould (1994) and subsequent research. There is an abundant literature on the link between migration and bilateral trade, for example by White (2009), Tadesse and White (2008), Bacarreza and Ehrlich (2006), Jansen and Piermartini (2005), Girma and Yu (2002), Head and Ries (1998), and Gould (1994). These studies indicate that migration has a significant impact on international (bilateral) trade, as the presence of migrants decreases trade and investment barriers. The validity of these findings is confirmed in a meta-analysis on the relationship between migration and trade (see Genc et al., 2010). Moreover, additional studies on the link between migration and international tourism have also shown a positive correlation between migration and international tourism, both on the basis of a

\footnotetext{
${ }^{1}$ Australia, Canada, China, France, Germany, Greece, India, Iran, Ireland, Italy, Jamaica, Japan, Malaysia, New Zealand, Pakistan, Poland, Portugal, South Africa, Spain, Sri Lanka, the Netherlands, and the United States.

${ }^{2}$ Australia, Bangladesh, Canada, China, France, Germany, Ghana, Greece, India, Ireland, Italy, Jamaica, Japan, Malaysia, New Zealand, Nigeria, Pakistan, Philippines, Poland, Portugal, South Africa, Spain, Sri Lanka, the Netherlands, the United States, Turkey, and Zimbabwe.
} 
meta-analysis and through case study research (see Gheasi et al. 2009). In contrast, the relationship between migration and FDI is an under-investigated area. A limited number of studies for example, Aroca and Maloney (2005), Tong (2005), Buch et al. (2006), Kugler and Rapoport (2007), Bhattacharya and Groznik (2008), Javorcik et al. (2010) and Federici and Giannetti (2010) have addressed this link, and they reported a positive and significant link between migration and FDI.

Table 1: The effect of immigration on FDI in various empirical studies

\begin{tabular}{|c|c|c|c|}
\hline Study & Sample & $\begin{array}{l}\text { Outward FDI } \\
\text { (elasticity) }\end{array}$ & $\begin{array}{l}\text { Inward FDI } \\
\text { (elasticity) }\end{array}$ \\
\hline Tong (2005) & $\begin{array}{l}\text { Ethnic Chinese and FDI position } \\
\text { between } 70 \text { countries, } 1990\end{array}$ & $0.19 * * *$ & $0.19 * * *$ \\
\hline Buch et al (2006) & 16 German states; $1990-2000$ & $\begin{array}{ll}0.01 & \text { (net stocks) } \\
0.48^{* *} & \text { (gross stocks) }\end{array}$ & $\begin{array}{r}0.06 * * \text { (net stocks) } \\
-0.10 \text { (gross stocks) }\end{array}$ \\
\hline $\begin{array}{l}\text { Kugler and Rapoport } \\
\text { (2007) }\end{array}$ & US outflows; 1990 and 2000 & $\begin{array}{l}0.22 *\left(\text { primary }^{1}\right) \\
-0.56\left(\text { secondary }^{2}\right) \\
0.44 * * *\left(\text { tertiary }^{3}\right)\end{array}$ & NA \\
\hline \multirow{2}{*}{$\begin{array}{l}\text { Bhattacharya and } \\
\text { Groznik (2008) }\end{array}$} & $\begin{array}{l}\text { Model A: US with } 33 \text { countries; } \\
1970,1980,1990 \text { and } 2000\end{array}$ & $0.33^{* *}$ & NA \\
\hline & $\begin{array}{l}\text { Model B: US with } 36 \text { countries; } \\
1970,1980,1990 \text { and } 2000\end{array}$ & $0.42^{* *}$ & NA \\
\hline Javorcik et al. (2010) & $\begin{array}{l}\text { US with } 56 \text { countries; } 1990 \text { and } \\
2000\end{array}$ & $\begin{array}{l}0.35^{* * *} \& 0.42 * * *(\text { stock }) \\
\left.0.41^{* * *} \& 0.52 * * * \text { tertiary }^{3}\right)\end{array}$ & NA \\
\hline
\end{tabular}

$* * *$ significant at $1 \%, * *$ significant at $5 \%$ and $*$ significant at $10 \%$.

1 migrants with primary education

2 migrants with secondary education

${ }^{3}$ migrants with tertiary education

Javorcik et al. (2010) have shown that the stock of US FDI abroad is positively correlated with the presence of migrants. Their study further indicates that the presence of migrants with a college education and of those with a higher education has a significant impact on FDI. It is interesting that a World Bank study shows that the outflows of FDI from the United States from a specific sector to a specific country are triggered by the existing share of laborers in that sector from that country (Aroca and Maloney, 2005). Next, Federici and Giannetti (2008) have also studied the link between migration and FDI, and they found a strong evidence of network externalities, which is mainly associated with the skilled diaspora. And finally, Buch et al. (2006) showed that German FDI outflows and migration inflows are strong complements. In conclusion, some fragmented statistical evidence is present on the relationship between migration and FDI. There is certainly a need for more solid empirical research. This will be presented with the next section.

\section{Estimation Approach}

The gravity model is the most commonly used model in the empirical literature to explain the variations in trade or investment between countries ( see van Bergeijk and Brakman, 2010). We will follow here the standard gravity equation that typically links bilateral flows of some sort between two places to their combined economic size (masses) and (negatively) to the geographic distance. The term physical mass can according to Isard et al. (1998) be replaced by many other indicators, such as size of the economy, population, income level, GDP and so on. This model is commonly used to explain variations in trade, but it can also be used for an analysis of FDI (Blonigen, 2005). 
The gravity model has been used for different spatial flow phenomena. For example, Karemera et al. (2000) used this model to test empirically determinants of international immigration and Porojan (2001) and Eaton and Kortum (1999) used this model to measure specific factors (technology, infrastructure and so on) in international trade, while Tong (2005), Javorcik et al. (2010) and Buch et al. (2006) used the gravity model to study the link between migration and foreign direct investment. Bhattacharya and Groznik (2008) employed the gravity model with cross-section dummy variables in studying the effect of migration on investment. The dummy variables approach for each partner country in Bhattacharya and Groznik (2005) avoids the need for strong theoretical underpinnings. We do not apply in our study cross-section dummies, because we aim to explore the effect of migrants on total investment positions, which requires data on the total number of migrants living in the UK. Therefore, an application of cross-section dummies is not a useful approach in our study. The general specification is:

$$
F D I_{i t}=f\left(M_{i t}, X_{i t}\right) \text {, }
$$

where $\mathrm{FDI}_{\mathrm{it}}$ is the UK's outward FDI to (or inward FDI from) country $\mathrm{i}$ at time $\mathrm{t} ; \mathrm{M}_{\mathrm{it}}$ denotes the stock of immigrants by foreign nationality from country $i$ living in the UK at time $t$, while $X_{i t}$ represents a vector of variables that influence bilateral FDI between the UK and partner country $i$ at time $t$. The gravity equation that we use to measure the impact of migration on the volume of FDI (inward and outward) is now:

$$
\ln F D I_{(U K-i) t}=\beta_{0}+\alpha_{1} \ln Y_{i t}+\alpha_{2} \ln M_{i t}+\alpha_{3} \ln P_{i t}+\alpha_{4} \ln D_{U K-i}+\alpha_{5} I_{i t}+\beta_{1} C o m m_{i}+\sum_{t=1}^{7} \gamma_{t} D_{i t}+\varepsilon_{i t},
$$

where all variables are measured in natural logarithms, apart from $\mathrm{I}_{\text {it }}$ (Insitutitional quality) and the dummy variables. The dependent variables $\left(\mathrm{FDI}_{(\mathrm{UK}-\mathrm{I}) \mathrm{t}}\right)$ are the inward and outward flows of FDI to and from the UK. The explanatory variables are defined as follows: $Y_{i t}$ is GDP per capita ${ }^{3}$ of country $i$ in constant US\$ at time $t ; M_{i t}$ is the stock of immigrants by nationality from country i living in the UK at time $t$; $P_{i t}$ is the total population of country $i$ at time $t$; $D_{U K-i}$ is the geographical distance between the UK and country $i$; $l_{i t}$ presents the institutional quality in country $i^{4}$ at time $t$. The latter variable is incorporates information on voice and accountability, political stability, government effectiveness, regulatory quality, rule of law, and control of corruption (see for details Kaufmann et al. 2009). $D_{\text {it }}$ is a time-dummy variable and $\mathrm{Comm}_{\mathrm{i}}$ is a dummy variable taking the value of 1 for Commonwealth countries and 0 , otherwise.

As model (2) does not take account of the endogeneity of the stock of immigrants with respect to the inward and outward stocks of FDI from and to the UK, we adopt here an instrumental variable approach to cope with the causality problem. For the choice of instrumental variables, we follow Javorcik et al. (2010), and we use the cost of obtaining a national passport in the original country $i$, normalized by the country's GDP per capita. McKenzie (2005) finds that higher passport costs are associated with outward immigration. In addition, we also use the 10-year lag of the total stock of

\footnotetext{
${ }^{3}$ Total population and GDP per capita of origin countries are used to capture the potential market size.

${ }^{4}$ This variable refers to the UK for the inward flows of FDI.
} 
migrants from each country living in the UK. The 10-year lag of stock of migrants is normalized by total population of each country at that time. Meanwhile, for some countries ${ }^{5}$ where data on the stock of migrants were not available for the year 1992, we used the stock of migrants for year 2001 instead. Javorcik et al. (2010) indicated that history of migration matters to encourage future flows. Moreover, we introduce two dummy variables: a dummy variable for Islamic countries, which takes the value of 1 if the country is an Islamic country and 0 , otherwise ${ }^{6}$, and a dummy variable for nonOECD countries, which takes the value of 1 , if the country is not a member of OECD, and 0 , otherwise.

\section{Data Sources}

In our study we used data from different sources. We use the World Development Indicators from the World Bank for GDP per capita at a constant US dollar value, and total population. GDP per capita and total population are used to estimate the potential market size. Next, our bilateral FDI and migration (the stock of foreign population by nationality) cross-section model was estimated for the UK, with 27 countries for outward FDI and 22 countries for inward FDI, using the OECD online database. FDI volumes were obtained from the OECD International Direct Investment Statistics Yearbook 2001-2007, while the stock of migrants (foreign population by nationality) has been obtained from the OECD international migration database for the years 2001-2007. Moreover, we also used the education level of immigrants from the OECD Database of immigrants and expatriates. This database identifies migrants by country of birth and also identifies whether they have a low (non-completed secondary school), medium (completed secondary school) or high (tertiary) educational attainment. These data are available only for one year (2001), but we used it to analyse the impact of immigrants' education on FDI investments during the years after. We used high and low education of immigrants in our analysis.

The institutional variable which represents the quality of the business climate is measured by using the average of voice and accountability, political stability, government effectiveness, regulatory quality, rule of law, and control of corruption from the 'governance matters' indicator developed by Kaufmann et al. (2009). The indicator ranges from 2.5, the highest quality of governance, to -2.5 , the lowest. Our geographical distance is measured in kilometers and taken from the www.cepii.fr website. This database provides relevant information, such as colonial ties, geographical distance and language etc.

The costs of a passport were derived from McKenzie (2005). This information is normalized by GDP per capita in the origin country. The passport cost for Zambabwe was taken from the Co-home Ministry, and for Iran from Wikipidia (biometric passport). As indicated by McKenzie (2005), the costs of a passport can be a barrier to outward migration. We also used a 10-year lag of stock of migrants from various countries living in the UK; it is normalized by total population in the source country. We have a dummy variable taking the value of 1 for Commonwealth countries, and 0 , otherwise. This

\footnotetext{
${ }^{5}$ Ghana, Nigeria, Poland and Zimbabwe.

${ }^{6}$ The Islamic dummy is relevant, since in most Islamic countries women face restrictions on foreign travel. Clearly, this may be one of the many barriers and cannot explain the overall restrictions on travel in several Islamic countries.
} 
variable is used to capture the language effect as well as the colonial tie between the UK and country i.

\section{Empirical Results}

\subsection{OLS results}

The data described in Section 4 were used as an input for an OLS regression analysis. The empirical results of this regresssion are presented in Table 2. The OLS results for inward FDI show that the model explains 79 and 87 percent of the variance in the error terms in both columns ( $I$ and II), respectively. The OLS results for the outward FDI stock explain 69 and 77 percent of the variance in both columns (III and IV), respectively. Hence, unobserved factors play a somewhat greater role in outward FDI than in inward FDI.

The estimated coefficients appear to have the theoretically expected signs. The most important link on the stock of immigrants is positively related to the outward volume of FDI and it is significant at a one percent significance level. This means that if the stock of immigrants (from the 27 countries considered) living in the UK increases by one percent, the outward FDI investment from the UK will increase by approx 0.60 percent. However, there is no significant relationship between the stock of immigrants and the inward volume of FDI, as appears from our OLS empirical results (column I). This shows that the stock of migrants has no significant effect on the total inward FDI from their country of origin to the UK.

It is often suggested that education matters in the impact assessment of migrants. And therefore, we included the education level of immigrants living in the UK. Our results show that immigrants with a higher education have a positive impact on both the inward and outward volume of FDI, respectively. We find that a one percent increase in the number of immigrants with a higher education from a source country into the UK, increases ceteris paribus the outward volume of FDI by 1.26 percent, while a one percent increase in the stock of immigrants with a higher education raises the inward stock of FDI by 1.48 percent, respectively. Thus, higher educated migrants have a higher impact on inward FDI to the UK. The presence of educated migrants in the UK apparently reduces the transaction cost of FDI in both directions. This is a rather robust finding, because other studies (see e.g. Javorcik et al., 2010) have also found some evidence that migrants with a higher education have a larger effect on FDI, while Guellec and Carvantes (2001) showed that sometimes FDI may flow to countries where there is already skilled labor available. They present as an empirical example Israel and India. At the same time, Ivlevs (2006) indicates theoretically that the presence of high-skilled immigrants may cause inward FDI flows to the host country. Our results show that for migrants with a lower education, a one percent increase in the number of lower educated migrants in the UK is associated with a 0.71 and 0.46 percent decrease in both directions of FDI (inward and outward), respectively.

The impact of the total population of the origin country is positively related to the inward and outward FDI and it is significant at one percent in all columns, respectively. This means that the UK receives FDI and invests more in countries with large markets (in terms of population). Besides, the GDP per capita of country i (a proxy for purchasing power) is positively related to both the inward 
and outward volume of FDI, and it is significant at a one percent level in both directions of investment, respectively. This means that the higher the GDP per capita of the country of origin, the higher the investment in the UK and the more FDI investment they acquire from the UK.

Table 2: OLS results (dependent variables = inward and outward FDI)

\begin{tabular}{|c|c|c|c|c|}
\hline & \multicolumn{2}{|c|}{ Inward FDI to the UK } & \multicolumn{2}{|c|}{ Outward FDI from the UK } \\
\hline & I & II & III & IV \\
\hline Stock of immigrants & $0.135(0.190)$ & & $0.603(0.138)^{* * *}$ & \\
\hline $\begin{array}{l}\text { Immigrants with higher } \\
\text { education }\end{array}$ & & $1.481(0.215)^{* * *}$ & & $1.260(0.138)^{* * *}$ \\
\hline $\begin{array}{l}\text { Immigrants with lower } \\
\text { education }\end{array}$ & & $-0.708(0.147)^{* * *}$ & & $-0.458(0.088)^{* * *}$ \\
\hline Population of country i & $1.186(0.091)^{* * *}$ & $0.856(0.103)^{* * *}$ & $0.236(0.075)^{* * *}$ & $0.236(0.050)^{* * *}$ \\
\hline GDP per capita of country $i$ & $2.216(0.133)^{* * *}$ & $1.803(0.147)^{* * *}$ & $0.794(0.121)^{* * *}$ & $0.696(0.113)^{* * *}$ \\
\hline Geographical distance & $-0.909(0.128)^{* * *}$ & $-0.838(0.134)^{* * *}$ & $-0.406(0.107)^{* * *}$ & $-0.585(0.111)^{* * *}$ \\
\hline Institutional quality & $6.651(2.147)^{* * *}$ & $6.628(1.858)^{* * *}$ & $0.285(0.221)$ & $0.152(0.201)$ \\
\hline Commonwealth & $2.200(0.456)^{* * *}$ & $1.183(0.456)^{* * *}$ & $0.542(0.252)^{* * *}$ & $0.216(0.263)$ \\
\hline Intercept & $-35.21(4.617)^{* * *}$ & $-35.57(3.607)^{* * *}$ & $-6.13(2.774)^{* * *}$ & $-5.37(1.881)^{* * *}$ \\
\hline Nr of observations & 150 & 150 & 189 & 189 \\
\hline $\mathrm{Nr}$ of countries & 22 & 22 & 27 & 27 \\
\hline R-square & 0.788 & 0.865 & 0.692 & 0.766 \\
\hline Time-dummy & Yes & Yes & Yes & Yes \\
\hline
\end{tabular}

The geographical distance between the UK and the origin countries plays a significant role in the inward and outward FDI to and from the UK. Our empirical results show that geographical distance is significant at a one percent level and is negatively related to both directions of FDI, respectively. Furthermore, some recent studies indicate that a larger geographical distance represents a greater cultural distance and thus, higher communication and information costs (see Buch et al., 2005).

The variable referring to institutional quality appears to be positively related to the outward and inward volume of FDI, respectively, while it is significant at a one percent level for inward FDI. For the inward FDI investment, we used the UK institutional quality. Our results show that this variable is significant and positively related to inward FDI. This is robust, as all previous studies also reported a positive and significant link between institutional quality and FDI. In addition, Wie (2000) and Habib and Zurawicki (2002) showed that corruption significantly reduces the inflows of investment, because poor quality of institutions that are necessary for the well functioning of business increases the cost of doing business and thus, reduces FDI.

The dummy variable for Commonwealth countries, which captures the language and colonial tie effect, is mostly significant at one percent and positively related (apart from column IV) to both directions of FDI, respectively. This variable has a larger impact on inward FDI than an outward FDI. This indicates that the UK attracts more FDI from Commonwealth countries in comparison with the UK's investments in Commonwealth countries. 


\subsection{Instrumental variables results}

It should be noted that FDI may also impact on migration flows. Thus, the above results from the OLS regression analysis may be biased and inconsistent, because of hidden endogeneity. In order to improve the above estimation results, we test the data for possible endogeneity of explanatory variables and unobserved heterogeneity. Therefore, we use an instrumental variables (IV) technique to test the possible endogeneity between the stock of foreign population by nationality living in the UK, education level of immigrants (immigrants with higher education (tertiary level) and immigrants with lower education) and the FDI (inward and outward direction). The education levels of immigrants are both incorporated in one regression based on instrumental variables. We followed the work by Javorcik et al. (2010) and used as instrumental variables: a 10-year lag of the stock of migrants from countries in our analysis living in the UK, normalized by total population of the source countries with for same year. As mentioned above, other instrumental variables are: passport cost (see McKenzie, 2005) normalized by GDP per capita, a dummy variable for Islamic countries, and a dummy variable for non-OECD countries.

As Table 3 shows, the instrumental variables are performing well and they explain significant parts of the stock of immigrants (both educated and non-educated). The under-identification test (Kleibergen-Paap statistics) in the second stage (Table 4) demonstrates that our estimation does not suffer from a weak instrument problem. The 10-year lag of stock of migrants normalized by total population of source country in the same year has the expected positive sign and it is statistically significant at one percent for the stock of migrants. This means that history of migration to the UK matters for the future inflow of migrants from countries considered in our analysis. However, the passport cost is positively related with the presence of immigrants in the UK. This is may be due the fact that most of the countries we used in our database are countries (apart from Turkey), where actual passport costs are not very prohibitive.

The dummy variable for Islamic countries has the expected negative sign, and it is mostly statistically significant (column I, II, IV, and V). This shows that the outward migration from Islamic countries is less than from non-Islamic countries. This may be due to our previous ${ }^{7}$ justification regarding female traveling from Islamic countries. Furthermore, the dummy variable for non-OECD countries is mostly positively related to migration, which probably means that the UK is a major destination for migrants from non-OECD countries.

As we can see from the second stage of our IV estimation (see Table 4), the stock of immigrants (obtained via the first stage of IV estimation) is positively related to both directions of FDI, and it is statistically significant in the outward FDI investment. This means that the stock of migrants living in the UK is a good predictor for the UK investment in the countries considered in our analysis. A one percent increase in the total stock of migrants is associated with a 0.25 percent increase in outward FDI from the UK. This is finding is supported by other studies: Javorcik et al. (2010) found from US data that a one percent increase in the stock of migrant from a certain country is associated with 0.35 to 0.42 percent increase in outward FDI from the US.

\footnotetext{
${ }^{7}$ See Section 4, footnote 6.
} 
The IV regression shows a robust result for the stock of immigrants with higher and lower education level in both directions of FDI in Table 4, respectively. This means that the higher the education level of immigrants living in the UK, the more effect they have on both directions of FDI, respectively. This finding is robust, and confirms the findings of Javorcik et al. (2010) and Docquier and Lodigiani (2008), who have also found evidence that the effect of migrants with higher education is larger. In conclusion, our main finding is that education matters for the impact of migrants. 
Table 3: The first stage of IV estimation (Dependent variable = the stock of immigrants in the UK)

\begin{tabular}{|c|c|c|c|c|c|c|}
\hline & \multicolumn{2}{|c|}{ Stock of migrants } & \multicolumn{2}{|c|}{ Migrants with higher education } & \multicolumn{2}{|c|}{ Migrants with lower education } \\
\hline & Inward (I) & Outward (II) & Inward (III) & Outward (IV) & Inward (V) & Outward (VI) \\
\hline Passport cost & $0.037(0.079)$ & $0.060(0.026)^{* * *}$ & $0.045(0.070)$ & $0.112(0.046)^{* * *}$ & $0.266(0.149)^{* *}$ & $0.029(0.042)$ \\
\hline $\begin{array}{l}\text { Share of migration to the UK in origin } \\
\text { country population (10-year lag) }\end{array}$ & $0.155(0.010)^{* * *}$ & $0.147(0.008)^{* * *}$ & $0.154(0.009)^{* * *}$ & $0.114(0.010)^{* * *}$ & $0.247(0.016)^{* * *}$ & $0.258(0.013)^{* * *}$ \\
\hline Islamic country & $-0.246(0.116)^{* * *}$ & $-0.459(0.109)^{* * *}$ & $0.035(0.096)$ & $-0.716(0.147)^{* * *}$ & $-0.606(0.271)^{* * *}$ & $-0.156(0.238)$ \\
\hline Non-OECD & $0.080(0.017)^{* * *}$ & $-0.526(0.139)^{* * *}$ & $0.018(0.012)$ & $0.166(0.151)$ & $0.009(0.031)$ & $-0.300(0.241)$ \\
\hline Centered R-square & 0.681 & 0.550 & 0.740 & 0.490 & 0.668 & 0.672 \\
\hline F test & 118.02 & 94.65 & 153.01 & 51.33 & 100.63 & 110.55 \\
\hline P-value & 0.000 & 0.000 & 0.000 & 0.000 & 0.000 & 0.000 \\
\hline Nr of observations & 150 & 189 & 150 & 189 & 150 & 189 \\
\hline Time-dummy & Yes & Yes & Yes & Yes & Yes & Yes \\
\hline
\end{tabular}

Robust standard errors are given in the parentheses. Legend: ${ }^{* * *}$ significant at $1 \%{ }^{* *}$ significant at $5 \%$ and ${ }^{*}$ significant at $10 \%$. Estimated parameters of other explanatory variables are not reported here. Details are available on request.

Table 4: The second stage of IV specification results (dependent variables = inward and outward stock of FDI)

\begin{tabular}{|c|c|c|c|c|}
\hline & \multicolumn{2}{|c|}{ Inward FDI to the UK } & \multicolumn{2}{|c|}{ Outward FDI from the UK } \\
\hline & I & II & III & IV \\
\hline Stock of immigrants & $0.111(0.198)$ & & $0.254(0.138)^{* *}$ & \\
\hline Immigrants with higher education & & $3.004(1.209)^{* * *}$ & & $1.250(0.419)^{* * *}$ \\
\hline Population of country $i$ & $1.208(0.083)^{* * *}$ & $0.572(0.212)^{* * *}$ & $0.266(0.067)^{* * *}$ & $0.247(0.043)^{* * *}$ \\
\hline GDP per capita of country $i$ & $2.180(0.133)^{* * *}$ & $1.339(0.329)^{* * *}$ & $0.805(0.121)^{* * *}$ & $0.711(0.109)^{* * *}$ \\
\hline Geographical distance & $-0.849(0.129)^{* * *}$ & $-0.900(0.170)^{* * *}$ & $-0.508(0.108)^{* * *}$ & $-0.612(0.121)^{* * *}$ \\
\hline Institutional quality & $6.944(2.068)^{* * *}$ & $6.658(2.003)^{* * *}$ & $0.262(0.214)$ & $0.121(0.210)$ \\
\hline Intercept & $-36.38(4.269)^{* * *}$ & $-35.57(3.607)^{* * *}$ & $-2.147(3.151)$ & $-4.991(2.273)^{* * *}$ \\
\hline Centered $\mathbf{R}^{2}$ & 0.790 & 0.775 & 0.684 & 0.766 \\
\hline Kleibergen-Paap test & 35.191 & 7.241 & 26.828 & 15.605 \\
\hline Prob>chi2 & 0.000 & 0.065 & 0.000 & 0.000 \\
\hline Nr of observations & 150 & 150 & 189 & 189 \\
\hline Time-dummy & Yes & Yes & Yes & Yes \\
\hline
\end{tabular}

Robust standard errors are given in the parentheses. Legend: ${ }^{* * *}$ significant at $1 \%,{ }^{* *}$ significant at $5 \%$ and ${ }^{*}$ significant at $10 \%$. 


\section{Concluding Remarks}

The purpose of this paper was to study the link between the stock of migrants in the UK and FDI (inward FDI and outward FDI). Previous studies have also suggested a linkage between migration and FDI. However, the linkage between the stock of migrants and FDI (inward and outward) to and from the UK has according to our knowledge not been previously explored. We used panel-pooled data for 22 countries for inward FDI and 27 countries for outward FDI during the period 2001 to 2007 . We also applied an instrumental variable approach to take into account the potential simultaneity between migration and FDI.

Our results show that the UK FDI abroad is positively related with the presence of migrants from a particular country. This result is plausible and in line with previous studies which also found that the stock of migrants in the host country serves as an important channel of information between host and origin country. The statistical results did not show a significant impact of migration on inward FDI to the UK. However, our findings further demonstrate that the presence of migrants with a higher education has a strong and positive effect on FDI investment in both directions. This means that educated migrants tend to have a positive effect on the economic integration of their country of origin with the host country and the global economy.

\section{References}

Aroca, P., and Maloney, W.F (2005). Migration, trade, and foreign direct investment in Mexico. The World Bank Economic Review 19: 449-472.

Bacarreza, G.J.C., and Ehrlich, L (2006). The impact of migration on foreign trade: a developing country approach. Latin American Journal of Economic Development 6: 125-146.

Bergeijk, P.A.G. van., and Brakman, S (2010). The gravity model in international trade. Cambridge University Press. Cambridge.

Blonigen, B.A (2005). A review of the empirical literature on FDI determinants. NBER Working Paper, no 11299. Cambridge.

Bhattacharya, U., and Groznik, P (2008). Melting pot or salad bowl: some evidence from U.S investment abroad. Journal of Financial Markets 11: 228-258.

Buch, C.M., Kleiner, J., Lipponer, A., and Toubal, F (2005). Determinants and effects of foreign direct investment: evidence from German firm-level data. Economic Policy 20:52-110.

Buch, C.M., Kleinert, J., and Toubal, F (2006). Where enterprises lead, people follow? Links between migration and FDI in Germany. European Economic Review 50: 2017-2036.

Docquier, F., and Lodigiani, E (2008). Skilled migration and business networks. Open Economies Review 21: 565-588.

Eaton, J., and Kortum, S (1999). International technology diffusion: theory and measurement. International Economic Review 40: 537-570. 
Federici, D., and Giannetti, M (2010). Temporary migration and foreign direct investment. Open Economies Review 21: 293-308.

Genc, M., Gheasi, M., Poot, J., and Nijkamp, P (2010). The impact of immigration on international trade: a meta-analysis. Presented at the NARSC conference. Denver, November 2010.

Gheasi, M., Nijkamp, P., and Rietveld, P (2010). Migration and tourist flows. In Tourism Economics: Impact Analysis, ed. A. Matias., P. Nijkamp., and M. Sarmento. Springer. Berlin (forthcoming).

Girma, S., and Yu, Z (2002). The link between immigration and trade: evidence from the United Kingdom. Weltwirtschaftliches Archiv 138: 115-130.

Gould, M. D (1994). Immigrant links to the home country: empirical implications for U.S bilateral trade flows. The Review of Economics and Statistics 76:302-316.

Guellec, D., and Cervantes, M (2001). International mobility of highly skilled workers: from statistical analysis to policy formulation. In International Mobility of the Highly Skilled. Organisation for Economic Co-operation and Development (OECD), Paris: 71-98.

Habib, M., and Zurawicki, L (2002). Corruption and foreign direct investment. Journal of International Business Studies. 33: 291-307.

Head, K., and Ries, J(1998). Immigration and trade creation: econometric evidence from Canada. The Canadian Journal of Economics 31: 47-62.

Isard, W,. Aziz I., Drennan M., Miller R., Saltzman S., and Thorbecke E (1998). Methods of Interregional and Regional Analysis. Ashgate Publisher. Aldershot.

Ivlevs, A (2006). Migration and foreign direct investment in the globalization context: the case of a small open economy. University of Milano. Development Working Papers from Centro Studi Luca d'Agliano No. 209. Milano.

Jansen, M., and Piermartini, R (2005). The impact of mode 4 liberalization on bilateral trade flows. Centre for Economic Policy Research (CEPR). Discussion paper No.5382. Geneva.

Javorcik, B., Ozden C., Spatareanu M., and Neagu C (2010). Migrant networks and foreign direct investment. Journal of Development Economics 94: 231-241.

Karemera, D., Iwuagwu Oguledo, V., and Davis, B (2000). A gravity model analysis of international migration to North America. Applied Economics 32: 1745 - 1755.

Kaufmann, D., Kraay, A., and Mastruzzi, M (2009). Governance matters VIII: aggregate and individual governance indicators, 1996-2008. World Bank Policy Research Working Paper No. 4978. Washington D.C.

Kugler, M., and Rapoport, H (2007). International labor and capital flows: complements or substitutes?. Economics Letters 94: 155-162.

McKenzie, D (2007) Paper wall are easier to tear down: passport costs and legal barriers to emigration. World Development 35: 2026-2039. 
Organization for Economic Co-operation and Development (OECD) (2008). International Migration Outlook: SOPEMI. OECD, Paris.

Porojan, A (2001). Trade flows and spatial effects: the gravity model revisited. Open Economies Review 12: 265- 280.

Tadesse, B., and White, R (2008). Do immigrants counter the effect of cultural distance on trade? evidence from the U.S state-level exports. The Journal of Socio-Economics 37: 2304-2318.

Tong, S (2005). Ethnic networks in FDI and the impact of institutional development. Review of Development Economics 9: 563-580.

United Nations Committee on Trade and Development (UNCTAD) (2006). World Investment Report. UNCTAD. Geneva.

White, R (2009). Immigration, trade and home country development: state-level variation in the US immigrant-export link. Journal of International Migration and Integration 10: 121-143.

Wei, S. J (2000). Local corruption and global capital flows. Brookings Papers on Economic Activity. 31: 303-354. 